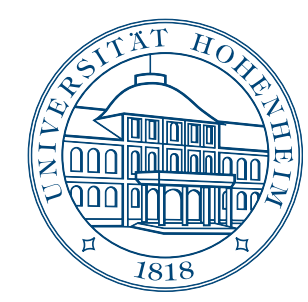

HOHENHEIM DISCUSSION PAPERS

IN BUSINESS, ECONOMICS AND SOCIAL SCIENCES

Research Area INEPA

DISCUSSION PAPER 11-2017

\title{
DIVERGENGE, CONVERGENCE, AND THE HISTORY-AUGMENTED SOLOW MODEL
}

Vadim Kufenko

University of Hohenheim

Klaus Prettner

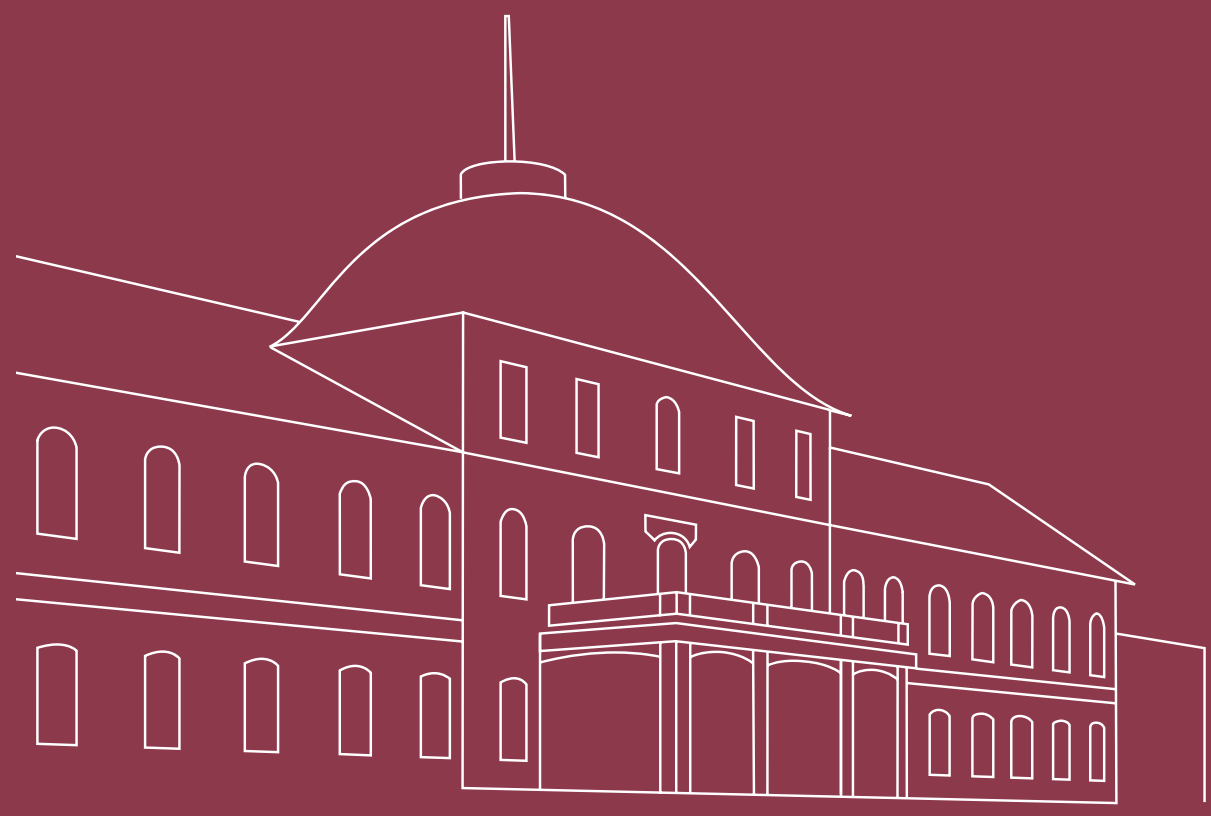

University of Hohenheim

Vincent Geloso

Texas Tech University 


\title{
Discussion Paper 11-2017
}

\section{Divergence, convergence, and the history-augmented Solow model}

\author{
Vadim Kufenko, Klaus Prettner, and Vincent Geloso \\ Research Area "INEPA - Inequality and Economic Policy Analysis"
}

\author{
Download this Discussion Paper from our homepage: \\ https://wiso.uni-hohenheim.de/papers
}

ISSN 2364-2076 (Printausgabe)

ISSN 2364-2084 (Internetausgabe)

Die Hohenheim Discussion Papers in Business, Economics and Social Sciences dienen der schnellen Verbreitung von Forschungsarbeiten der Fakultät Wirtschafts- und Sozialwissenschaften. Die Beiträge liegen in alleiniger Verantwortung der Autoren und stellen nicht notwendigerweise die Meinung der Fakultät Wirtschafts- und Sozialwissenschaften dar.

Hohenheim Discussion Papers in Business, Economics and Social Sciences are intended to make results of the Faculty of Business, Economics and Social Sciences research available to the public in order to encourage scientific discussion and suggestions for revisions. The authors are solely responsible for the contents which do not necessarily represent the opinion of the Faculty of Business, Economics and Social Sciences. 


\title{
Divergence, convergence, and the history-augmented Solow model
}

\author{
Vadim Kufenko $^{a}$, Klaus Prettner ${ }^{a}$, and Vincent Geloso ${ }^{b *}$ \\ a) University of Hohenheim \\ Institute of Economics \\ Schloss, Osthof-West, \\ 70593 Stuttgart, Germany \\ b) Free Market Institute \\ Texas Tech University \\ Box 45059, Lubbock, TX, 79409-5059, United States
}

\begin{abstract}
We test the history-augmented Solow model with respect to its predictions on the patterns of divergence and convergence between the nowadays industrialized countries of the OECD. We show that the dispersion of incomes increased after the Industrial Revolution, peaked during the Second World War, and decreased afterwards. This pattern is fully consistent with the transitional dynamics implied by the historyaugmented Solow model.
\end{abstract}

JEL classification: J11, O11, O47.

Keywords: History-augmented Solow model, divergence, convergence, cross-country inequality.

${ }^{*}$ Vadim Kufenko and Klaus Prettner gratefully acknowledge the support provided by the Faculty of Business, Economics, and Social Sciences at the University of Hohenheim within the research area "Inequality and Economic Policy Analysis (INEPA)". 


\section{Introduction}

From a historical perspective, today's industrialized countries have seen their incomes diverge during the Industrial Revolution. The main reason for this divergence is the differential timing in the takeoff to sustained economic growth as implied by the unified growth theory of Galor and Weil (2000) and Galor (2005, 2011), and as quantified for different countries in terms of the timing of the demographic transition by Reher (2004). In later phases of development, however, club convergence has been observed in the sense that income differences narrowed between countries with similar steady-state characteristics such as the members of the OECD (see, for example, Barro, 1997; Sala-i-Martin, 1997; Barro and Sala-i-Martin, 2004). Most recently, Dalgaard and Strulik (2013) proposed the history-augmented Solow (1956) model to reconcile these two dynamics by accounting for the differential takeoff to growth in an otherwise standard convergence growth regression. They show that their model-based estimates i) have a higher explanatory power than the standard approach with respect to the observed long-run income differences between different countries; ii) do not suffer from the otherwise common anomaly in growth regressions that the estimate of the capital share is exceedingly high.

While Dalgaard and Strulik (2013) focus on the long-run steady-state implications of their framework, we analyze the country-specific trajectories of per capita income as implied by the transition path of their model. Our test of the model is based on the notion of $\sigma$-convergence (Young et al., 2008), i.e., the change in the dispersion of income levels between different countries over time. If the history-augmented Solow model is an accurate description of the underlying data-generating process, then one should observe an increasing dispersion of incomes first, then a structural break, and finally a reduction in the dispersion of incomes. We show that this is indeed the case by relying on long-run data of per capita GDP. Our results give credence to the history-augmented Solow model and offer additional insights into the dynamics of cross-country inequality over a long time horizon.

\section{The implications of the history-augmented Solow model for convergence}

Following Dalgaard and Strulik (2013), we consider a production function along the lines of Solow (1956)

$$
Y(t)=K(t)^{\alpha}[A(t) L(t)]^{1-\alpha},
$$

where $Y(t)$ is aggregate output at time $t, K(t)$ is the input of physical capital in the production process, $L(t)$ is employment in production, $A(t)$ is the stock of labor-augmenting technology, and $\alpha$ is the elasticity of output with respect to physical capital. For a constant savings rate $s \in(0,1)$, a constant rate of depreciation $\delta \in(0,1)$, and a constant population growth rate $n \geq 0$, it is well-known that income per efficiency unit of labor, $\hat{y}(t)=$ 
$Y(t) /[A(t) L(t)]$, is constant at the steady state and given by $\hat{y}^{*}=[s /(n+g+\delta)]^{\alpha /(1-\alpha)}$. Consequently, per capita income along the balanced growth path is driven by the evolution of technology according to the relationship

$$
y(t)=A(t)\left(\frac{s}{n+g+\delta}\right)^{\frac{\alpha}{1-\alpha}},
$$

where $A(t)$ grows at the rate of technological progress as given by $g=\dot{A} / A$. Assuming, as in Dalgaard and Strulik (2013), that the takeoff to positive long-run growth occurred at time $\tau<t$, the economy experienced ongoing per capita income growth since $t-\tau$ years. Altogether, this implies that per capita income in the long run is given by

$$
y(t)=A(\tau) e^{g(t-\tau)}\left(\frac{s}{n+g+\delta}\right)^{\frac{\alpha}{1-\alpha}}
$$

where $A(\tau)$ is the level of technology at the time of the takeoff to sustained growth. Countries that experienced an earlier takeoff (i.e., countries with a lower $\tau$ ) have a higher per capita income as of time $t$. Dalgaard and Strulik (2013) use this equation to derive a cross-country growth regression equation by which they test their history-augmented Solow model. They find that adding a proxy for the differential timing of the takeoff based upon the data of Reher (2004) - greatly enhances the explanatory power of crosscountry growth regressions and solves the issue that most standard growth regressions exhibit an exceedingly high coefficient estimate for the elasticity of output with respect to physical capital, $\alpha$.

There is, however, another highly interesting implication of the model that is due to its implied transitional dynamics. Since different countries are very similar before the onset of the industrial revolution in terms of their income levels, the differential takeoff leads countries to diverge in terms of their income levels after the first countries experience their takeoff. As more and more countries transition toward sustained long-run growth, however, the dispersion peaks at some point and afterwards it starts to decline. We display the simulated trajectories of the history-augmented Solow model in Figure 1 for five different groups of countries that can be interpreted as forerunners, followers, latecomers, and trailers according to the classification of Reher (2004). In case of the latecomers we assume for illustrative purposes that there are two types of countries. The first group has a gross savings rate of $s=0.3$, while the second group has a higher gross savings rate of $s=0.4$. The associated coefficient of variation between the income levels of the different country groups is displayed in Figure 2. We observe that the dispersion increases first and decreases afterwards. In the next section we test whether this pattern is consistent with the pattern of divergence and convergence that we observe in the data. 


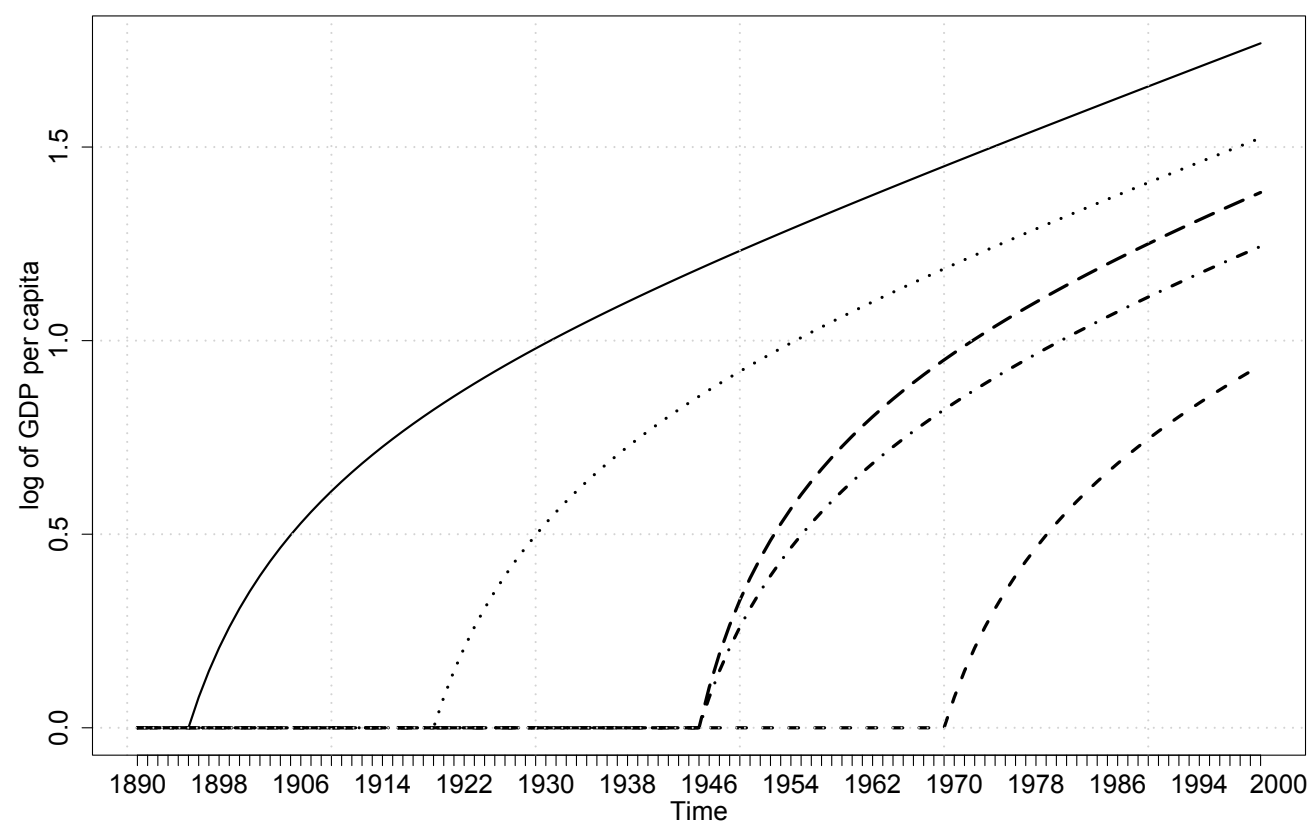

Figure 1: Simulated trajectories for the differential takeoff of five different groups of countries according to the history-augmented Solow model.

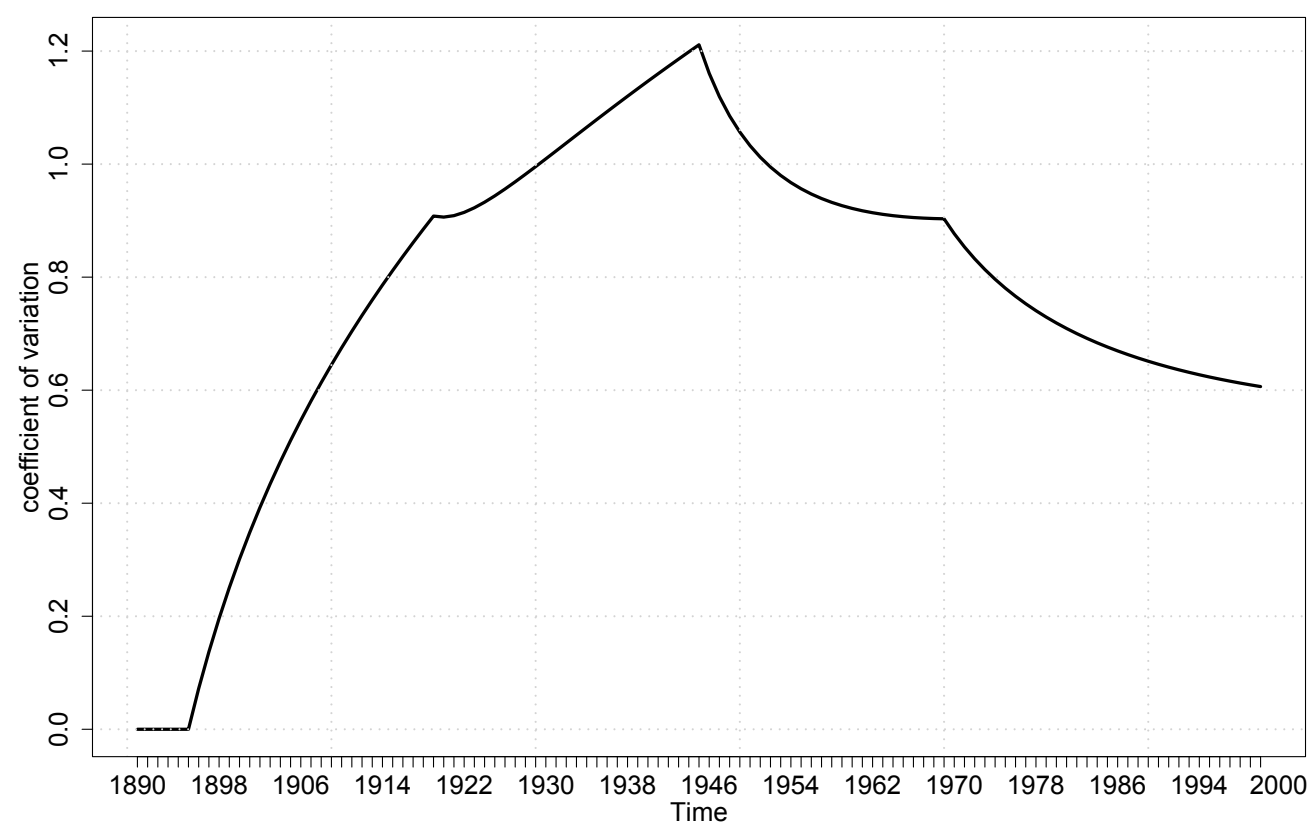

Figure 2: Coefficient of variation associated with the simulation of the history-augmented Solow model. 


\section{Main results}

In order to test the implications of the history-augmented Solow model, we calculate the coefficient of variation for per capita output in the long run and analyze the data as a time series to identify the slopes and breakpoints, providing they exist. We use the data of Bolt and Zanden (2014) which covers the GDP and population series for the following OECD countries: Australia, Canada, England, Finland, France, Greece, Hungary, Ireland, Japan, the Netherlands, New Zealand, South Korea, Sweden, and the United States between 1890 and 2000. To tackle the changes in the composition of the sample over time and the associated size effects, we weight the GDP per capita series by the population size. Doing so yields a smoother series as compared to the unweighted one.

First, we apply the structural break test of Bai and Perron (2003), which was implemented in the software package "R" by Zeileis et al. $(2002,2003)$. The minimal size of segments is set to 30 and the number of structural breaks is set to one, which is a reasonalbe assumption, given the theoretical implications. The Bai-Perron test yields 1942 as the breakpoint: a brief visual examination shows that indeed, the coefficient of variation has been increasing before the breakpoint and decreasing afterwards (see Figure 3). In order to quantify the slope before and after the breakpoint, we apply a segmented regression as in Muggeo $(2003,2008)$. In so doing we use the result of the Bai-Perron test as the initial guess of the breakpoint $\psi^{(0)}$. The advantage of the used method is that it updates the breakpoint estimate through iterations, yielding a final value $\hat{\psi}$ of 1949. The results of this procedure are presented in Table 1 and yield a significantly positive slope before the breakpoint and a significantly negative slope afterwards. The annual increase of the population weighted coefficient of variation before the breakpoint is given by $1.39 \%$, whereas the annual decrease after the breakpoint is $0.972 \%$. These results show that there has been a significant divergence between the different countries until the end of the Second World War, whereas thereafter the results are consistent with the notion of gradual club convergence.

Table 1: Segmented regression estimates of the slopes of the trends

\begin{tabular}{lr}
\hline Dependent variable: Population-weighted coefficient of variation of per capita GDP \\
\hline $\mathrm{t}<\hat{\psi}$ & $0.0139^{* * *}$ \\
& $(0.0006)$ \\
$\mathrm{t}>\hat{\psi}$ & $-0.00972^{* * *}$ \\
& $(0.00072)$ \\
\hline Initial breakpoint $\left[\psi^{(0)}\right]$ from Bai and Perron $(2003)$ & 1942 \\
Updated $\hat{\psi}$ & 1949 \\
Adjusted R sq. & 0.8829 \\
\hline \multicolumn{2}{c}{ Note: Standard errors are reported in parentheses. ${ }^{* * *} \mathrm{p}<0.01,{ }^{* *} \mathrm{p}<0.05,{ }^{*} \mathrm{p}<0.1$}
\end{tabular}




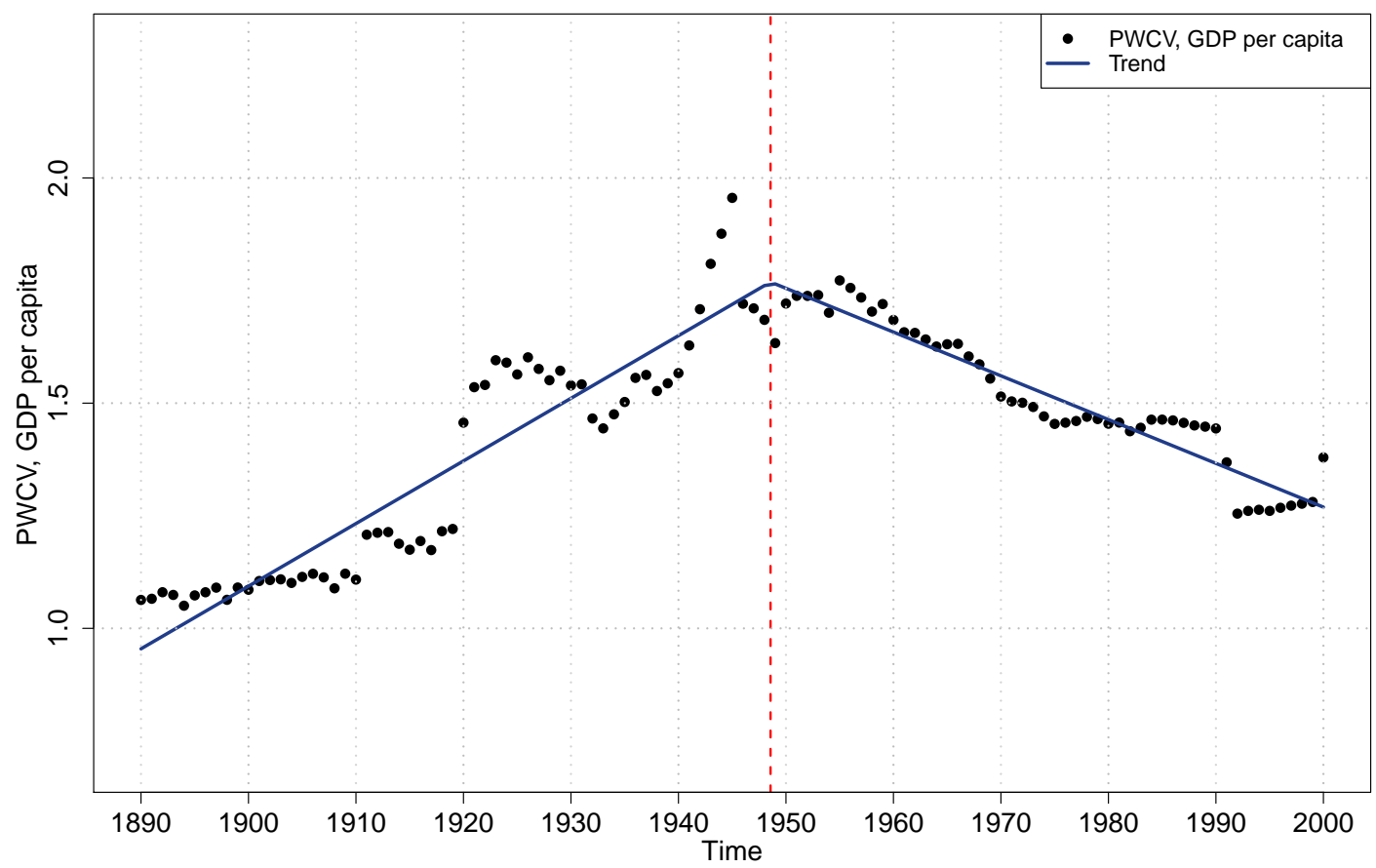

Figure 3: Population-weigthed coefficient of variation of per capita GDP; breakpoint and segmented trend estimation.

\section{Conclusions}

We put the history-augmented Solow model with respect to its predictions on cross-country divergence and convergence since the Industrial Revolution to the test. The transition phase toward the long-run steady state of the model implies increasing dispersion of incomes first and decreasing dispersion in later phases. This pattern is supported by the data for the nowadays industrialized OECD countries, which gives further credence to the history-augmented Solow model as suggested by Dalgaard and Strulik (2013).

\section{References}

Bai, J. and Perron, P. (2000). Computation and Analysis of Multiple Structural Change Models. Journal of Applied Econometrics, Vol. 18(No. 1):1-22.

Barro, R. J. (1997). Determinants of Economic Growth: A Cross-Country Empirical Study. MIT Press, Cambridge MA.

Barro, R. J. and Sala-i-Martin, X. S. (2004). Economic Growth. The MIT Press. Cambridge, Mass.

Bolt, J. and van Zanden, J. D. (2014). The Maddison Project: Collaborative Research on Historical National Accounts. The Economic History Review, Vol. 67(No. 3):627-651. 
Dalgaard, C.-J. and Strulik, H. (2013). The history augmented solow model. European Economic Review, Vol. 63:134-149.

Galor, O. (2005). Handbook of Economic Growth, chapter 4. "From Stagnation to Growth: Unified Growth Theory", pages 171-293.

Galor, O. (2011). Unified Growth Theory. Princeton University Press.

Galor, O. and Weil, D. (2000). Population, Technology, and Growth: From Malthusian Stagnation to the Demographic Transition and Beyond. The American Economic Review, Vol. 90(No. 4):806-828.

Geloso, V., Kufenko, V., and Prettner, K. (2016). Demographic change and regional convergence in Canada. Economics Bulletin, Vol. 36(No. 4):1904-1910.

Muggeo, Vito M. R. (2003). Estimating Regression Models with Unknown Break-points. Statistics in Medicine, Vol. 22(No. 19):3055-3071.

Muggeo, Vito M. R. (2008). Segmented: an R package to fit Regression Models with Broken-line Relationships (Ver. 0.5-2.1). R News, Vol. 8(No. 1):20-25.

Reher, D. S. (2004). The Demographic Transition Revisited as a Global Process. Population, Space and Place, Vol. 10:19-41.

Sala-i-Martin, X. (1997). I just ran two million regressions. American Economic Review, Vol. 87 (No. 2).

Solow, R. M. (1956). A contribution to the theory of economic growth. The Quarterly Journal of Economics, Vol. 70(No. 1):65-94.

Young, A. T., Higgins, M. J., and Levy, D. (2008). Sigma Convergence versus Beta Convergence: Evidence from U.S. County-Level Data. Journal of Money, Credit and Banking, Vol. 40(No. 5):1083-1093.

Zeileis, A., Leisch, F., Hornik, K., and Kleiber, C. (2002). strucchange: An R Package for Testing for Structural Change in Linear Regression Models (Ver. 1.5-1). Journal of Statistical Software, Vol. 7(No. 2):1-38.

Zeileis, A., Kleiber, C., Kraemer, W., Hornik, K. (2003). Testing and Dating of Structural Changes in Practice. Computational Statistics \& Data Analysis, Vol. 44:109-123. 


\section{Hohenheim Discussion Papers in Business, Economics and Social Sciences}

The Faculty of Business, Economics and Social Sciences continues since 2015 the established "FZID Discussion Paper Series" of the "Centre for Research on Innovation and Services (FZID)" under the name "Hohenheim Discussion Papers in Business, Economics and Social Sciences".

\section{Institutes}

$510 \quad$ Institute of Financial Management

520 Institute of Economics

530 Institute of Health Care \& Public Management

540 Institute of Communication Science

550 Institute of Law and Social Sciences

560 Institute of Economic and Business Education

570 Institute of Marketing \& Management

580 Institute of Interorganisational Management \& Performance

\section{Research Areas (since 2017)}

INEPA "Inequality and Economic Policy Analysis"

TKID "Transformation der Kommunikation - Integration und Desintegration"

NegoTrans "Negotiation Research - Transformation, Technology, Media and Costs"

INEF "Innovation, Entrepreneurship and Finance"

Download Hohenheim Discussion Papers in Business, Economics and Social Sciences from our homepage: https://wiso.uni-hohenheim.de/papers

\section{No. Author \\ 01-2015 Thomas Beissinger, Philipp Baudy}

02-2015 Fabian Wahl

03-2015 Tommaso Proietti, Martyna Marczak, Gianluigi Mazzi

04-2015 Thomas Beissinger, Nathalie Chusseau, Joël Hellier

05-2015 Matthias Mueller, Kristina Bogner, Tobias Buchmann, Muhamed Kudic

06-2015 Martyna Marczak, Thomas Beissinger

07-2015 Peng Nie, Galit Nimrod, Alfonso Sousa-Poza
Title Inst

THE IMPACT OF TEMPORARY AGENCY WORK 520 ON TRADE UNION WAGE SETTING:

A Theoretical Analysis

PARTICIPATIVE POLITICAL INSTITUTIONS AND CITY DEVELOPMENT 800-1800

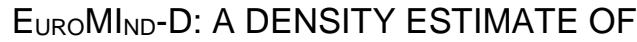
MONTHLY GROSS DOMESTIC PRODUCT FOR THE EURO AREA

OFFSHORING AND LABOUR MARKET REFORMS: MODELLING THE GERMAN EXPERIENCE

SIMULATING KNOWLEDGE DIFFUSION IN FOUR 520 STRUCTURALLY DISTINCT NETWORKS - AN AGENT-BASED SIMULATION MODEL

BIDIRECTIONAL RELATIONSHIP BETWEEN 520 INVESTOR SENTIMENT AND EXCESS RETURNS: NEW EVIDENCE FROM THE WAVELET PERSPECTIVE

INTERNET USE AND SUBJECTIVE WELL-BEING IN CHINA 
No. Author

Title

Inst

08-2015 Fabian Wahl

09-2015 Peng Nie, Alfonso Sousa-Poza

10-2015 Kristina Bogner

11-2015 Bogang Jun, Tai-Yoo Kim

12-2015 Volker Grossmann Aderonke Osikominu Marius Osterfeld

13-2015 Martyna Marczak Tommaso Proietti Stefano Grassi

14-2015 Carolina Castagnetti Luisa Rosti Marina Töpfer

15-2015 Alexander Opitz

01-2016 Michael Ahlheim, Jan Neidhardt

02-2016 Bogang Jun, Alexander Gerybadze, Tai-Yoo Kim

03-2016 Peng Nie, Alfonso Sousa-Poza

04-2016 Peter Spahn

05-2016 Vincent Dekker, Kristina Strohmaier, Nicole Bosch

06-2016 Philipp Baudy, Dario Cords
THE LONG SHADOW OF HISTORY

ROMAN LEGACY AND ECONOMIC DEVELOPMENT

520

- EVIDENCE FROM THE GERMAN LIMES

COMMUTE TIME AND SUBJECTIVE WELL-BEING IN URBAN CHINA

530

THE EFFECT OF PROJECT FUNDING ON INNOVATIVE PERFORMANCE AN AGENT-BASED SIMULATION MODEL

520

A NEO-SCHUMPETERIAN PERSPECTIVE ON THE ANALYTICAL MACROECONOMIC FRAMEWORK: THE EXPANDED REPRODUCTION SYSTEM

ARE SOCIOCULTURAL FACTORS IMPORTANT FOR STUDYING A SCIENCE UNIVERSITY MAJOR?

520

A DATA-CLEANING AUGMENTED KALMAN FILTER FOR ROBUST ESTIMATION OF STATE SPACE MODELS

520

THE REVERSAL OF THE GENDER PAY GAP AMONG PUBLIC-CONTEST SELECTED YOUNG EMPLOYEES

520

DEMOCRATIC PROSPECTS IN IMPERIAL RUSSIA: THE REVOLUTION OF 1905 AND THE POLITICAL STOCK MARKET

NON-TRADING BEHAVIOUR IN CHOICE EXPERIMENTS

THE LEGACY OF FRIEDRICH LIST: THE EXPANSIVE REPRODUCTION SYSTEM AND THE KOREAN HISTORY OF INDUSTRIALIZATION

FOOD INSECURITY AMONG OLDER EUROPEANS: 530 EVIDENCE FROM THE SURVEY OF HEALTH, AGEING, AND RETIREMENT IN EUROPE

POPULATION GROWTH, SAVING, INTEREST RATES AND STAGNATION. DISCUSSING THE EGGERTSSONMEHROTRA-MODEL

A DATA-DRIVEN PROCEDURE TO DETERMINE THE BUNCHING WINDOW - AN APPLICATION TO THE NETHERLANDS

DEREGULATION OF TEMPORARY AGENCY EMPLOYMENT IN A UNIONIZED ECONOMY: DOES THIS REALLY LEAD TO A SUBSTITUTION OF REGULAR EMPLOYMENT? 
No.

07-2016

Robin Jessen, Davud Rostam-Afschar, Sebastian Schmitz

08-2016 Peng Nie, Alfonso Sousa-Poza, Jianhong Xue

09-2016 Bogang Jun, Seung Kyu-Yi, Tobias Buchmann, Matthias Müller

10-2016 Vladan Ivanovic, Vadim Kufenko, Boris Begovic Nenad Stanisic, Vincent Geloso

11-2016 David E. Bloom Michael Kuhn Klaus Prettner

12-2016 Franz X. Hof Klaus Prettner

13-2016 Jung-In Yeon Andreas Pyka Tai-Yoo Kim

14-2016 Benjamin Fuchs

15-2016 Seung-Kyu Yi Bogang Jun

16-2016 Gregor Pfeifer Fabian Wahl Martyna Marczak

17-2016 Malte Klein Andreas Sauer

18-2016 Klaus Prettner

19-2016 Klaus Prettner Andreas Schaefer

20-2016 Vadim Kufenko Klaus Prettner
Title

Inst

HOW IMPORTANT IS PRECAUTIONARY LABOR

520 SUPPLY?

FUEL FOR LIFE: DOMESTIC COOKING FUELS AND 530 WOMEN'S HEALTH IN RURAL CHINA

THE CO-EVOLUTION OF INNOVATION NETWORKS: 520 COLLABORATION BETWEEN WEST AND EAST GERMANY FROM 1972 TO 2014

CONTINUITY UNDER A DIFFERENT NAME. 520 THE OUTCOME OF PRIVATISATION IN SERBIA

THE CONTRIBUTION OF FEMALE HEALTH TO ECONOMIC DEVELOPMENT GROWTH

STRUCTURAL SHIFT AND INCREASING VARIETY IN KOREA, 1960-2010: EMPIRICAL EVIDENCE OF THE ECONOMIC DEVELOPMENT MODEL BY THE CREATION OF NEW SECTORS

THE EFFECT OF TEENAGE EMPLOYMENT ON CHARACTER SKILLS, EXPECTATIONS AND OCCUPATIONAL CHOICE STRATEGIES

HAS THE GERMAN REUNIFICATION 520 STRENGTHENED GERMANY'S NATIONAL INNOVATION SYSTEM? TRIPLE HELIX DYNAMICS OF GERMANY'S INNOVATION SYSTEM

ILLUMINATING THE WORLD CUP EFFECT: NIGHT LIGHTS EVIDENCE FROM SOUTH AFRICA

CELEBRATING 30 YEARS OF INNOVATION 570 SYSTEM RESEARCH: WHAT YOU NEED TO KNOW ABOUT INNOVATION SYSTEMS

THE IMPLICATIONS OF AUTOMATION FOR ECONOMIC GROWTH AND THE LABOR SHARE

HIGHER EDUCATION AND THE FALL AND RISE OF INEQUALITY

520

YOU CAN'T ALWAYS GET WHAT YOU WANT? 520 ESTIMATOR CHOICE AND THE SPEED OF CONVERGENCE 
No.

\section{Author} Alberto Bucci Klaus Prettner

02-2017 Julius Tennert Marie Lambert Hans-Peter Burghof

03-2017 Michael Ahlheim Oliver Frör Nguyen Minh Duc Antonia Rehl Ute Siepmann Pham Van Dinh

04-2017 Bohdan Kukharskyy Sebastian Seiffert

05-2017 Ana Abeliansky Klaus Prettner

06-2017 Vincent Geloso Vadim Kufenko

07-2017 Emanuel Gasteiger Klaus Prettner

08-2017 Klaus Prettner Holger Strulik

09-2017 David E. Bloom Simiao Chen Michael Kuhn Mark E. McGovern Les Oxley Klaus Prettner

10-2017 Sebastian Till Braun Nadja Dwenger

11-2017 Vadim Kufenko Klaus Prettner Vincent Geloso
Title

CHILDRENS HEALTH, HUMAN CAPITAL ACCUMULATION, AND R\&D-BASED ECONOMIC

Inst

INEPA GROWTH

MORAL HAZARD IN VC-FINANCE: MORE

INEF EXPENSIVE THAN YOU THOUGHT

LABOUR AS A UTILITY MEASURE RECONSIDERED 520

GUN VIOLENCE IN THE U.S.: CORRELATES AND 520 CAUSES

AUTOMATION AND DEMOGRAPHIC CHANGE 520

INEQUALITY AND GUARD LABOR, OR INEPA PROHIBITION AND GUARD LABOR?

ON THE POSSIBILITY OF AUTOMATION-INDUCED STAGNATION

THE LOST RACE AGAINST THE MACHINE: AUTOMATION, EDUCATION, AND INEQUALITY IN AN R\&D-BASED GROWTH MODEL

THE ECONOMIC BURDEN OF CHRONIC 520 DISEASES: ESTIMATES AND PROJECTIONS FOR CHINA, JAPAN, AND SOUTH KOREA

THE LOCAL ENVIRONMENT SHAPES REFUGEE INTEGRATION: EVIDENCE FROM POST-WAR GERMANY

DIVERGENCE, CONVERGENCE, AND THE HISTORY-AUGMENTED SOLOW MODEL
INEPA

INEPA 
(published 2009-2014)

\section{Competence Centers}

IK Innovation and Knowledge

ICT Information Systems and Communication Systems

CRFM Corporate Finance and Risk Management

$\mathrm{HCM} \quad$ Health Care Management

CM Communication Management

MM Marketing Management

ECO Economics

Download FZID Discussion Papers from our homepage: https://wiso.uni-hohenheim.de/archiv_fzid_papers

\begin{tabular}{|c|c|c|c|}
\hline Nr. & Autor & Titel & CC \\
\hline 01-2009 & Julian P. Christ & $\begin{array}{l}\text { NEW ECONOMIC GEOGRAPHY RELOADED: } \\
\text { Localized Knowledge Spillovers and the Geography of Innovation }\end{array}$ & IK \\
\hline 02-2009 & André P. Slowak & $\begin{array}{l}\text { MARKET FIELD STRUCTURE \& DYNAMICS IN INDUSTRIAL } \\
\text { AUTOMATION }\end{array}$ & IK \\
\hline 03-2009 & $\begin{array}{l}\text { Pier Paolo Saviotti, } \\
\text { Andreas Pyka }\end{array}$ & $\begin{array}{l}\text { GENERALIZED BARRIERS TO ENTRY AND ECONOMIC } \\
\text { DEVELOPMENT }\end{array}$ & IK \\
\hline 04-2009 & $\begin{array}{l}\text { Uwe Focht, Andreas } \\
\text { Richter and Jörg } \\
\text { Schiller }\end{array}$ & INTERMEDIATION AND MATCHING IN INSURANCE MARKETS & $\mathrm{HCM}$ \\
\hline 05-2009 & $\begin{array}{l}\text { Julian P. Christ, } \\
\text { André P. Slowak }\end{array}$ & $\begin{array}{l}\text { WHY BLU-RAY VS. HD-DVD IS NOT VHS VS. BETAMAX: } \\
\text { THE CO-EVOLUTION OF STANDARD-SETTING CONSORTIA }\end{array}$ & IK \\
\hline 06-2009 & $\begin{array}{l}\text { Gabriel Felbermayr, } \\
\text { Mario Larch and } \\
\text { Wolfgang Lechthaler }\end{array}$ & UNEMPLOYMENT IN AN INTERDEPENDENT WORLD & ECO \\
\hline 07-2009 & Steffen Otterbach & $\begin{array}{l}\text { MISMATCHES BETWEEN ACTUAL AND PREFERRED WORK } \\
\text { TIME: Empirical Evidence of Hours Constraints in } 21 \text { Countries }\end{array}$ & $\mathrm{HCM}$ \\
\hline 08-2009 & Sven Wydra & $\begin{array}{l}\text { PRODUCTION AND EMPLOYMENT IMPACTS OF NEW } \\
\text { TECHNOLOGIES - ANALYSIS FOR BIOTECHNOLOGY }\end{array}$ & IK \\
\hline 09-2009 & $\begin{array}{l}\text { Ralf Richter, } \\
\text { Jochen Streb }\end{array}$ & $\begin{array}{l}\text { CATCHING-UP AND FALLING BEHIND } \\
\text { KNOWLEDGE SPILLOVER FROM AMERICAN } \\
\text { TO GERMAN MACHINE TOOL MAKERS }\end{array}$ & IK \\
\hline
\end{tabular}


Nr.

Autor

Titel

CC

KYOTO AND THE CARBON CONTENT OF TRADE

ECO

Gabriel Felbermayr

11-2010 David E. Bloom,

ECONOMIC CONSEQUENCES OF LOW FERTILITY IN EUROPE

$\mathrm{HCM}$

Alfonso Sousa-Poza

12-2010 Michael Ahlheim, Oliver Frör

DRINKING AND PROTECTING - A MARKET APPROACH TO THE PRESERVATION OF CORK OAK LANDSCAPES

ECO

LABOUR AS A UTILITY MEASURE IN CONTINGENT VALUATION STUDIES - HOW GOOD IS IT REALLY?

ECO

Oliver Frör,

Antonia Heinke,

Nguyen Minh Duc,

and Pham Van Dinh

14-2010 Julian P. Christ

THE GEOGRAPHY AND CO-LOCATION OF EUROPEAN

IK

TECHNOLOGY-SPECIFIC CO-INVENTORSHIP NETWORKS

15-2010 Harald Degner

WINDOWS OF TECHNOLOGICAL OPPORTUNITY

DO TECHNOLOGICAL BOOMS INFLUENCE THE RELATIONSHIP BETWEEN FIRM SIZE AND INNOVATIVENESS?

16-2010 Tobias A. Jopp

THE WELFARE STATE EVOLVES:

GERMAN KNAPPSCHAFTEN, 1854-1923

$\mathrm{HCM}$

17-2010 Stefan Kirn (Ed.)

PROCESS OF CHANGE IN ORGANISATIONS THROUGH

ICT

eHEALTH

18-2010 Jörg Schiller

ÖKONOMISCHE ASPEKTE DER ENTLOHNUNG

$\mathrm{HCM}$

UND REGULIERUNG UNABHÄNGIGER

VERSICHERUNGSVERMITTLER

19-2010 Frauke Lammers,

CONTRACT DESIGN AND INSURANCE FRAUD: AN

$\mathrm{HCM}$

Jörg Schiller

EXPERIMENTAL INVESTIGATION

REAL WAGES AND THE BUSINESS CYCLE IN GERMANY

ECO

Thomas Beissinger

21-2010 Harald Degner,

Jochen Streb

FOREIGN PATENTING IN GERMANY, 1877-1932

IK

DOES DOWNWARD NOMINAL WAGE RIGIDITY

DAMPEN WAGE INCREASES?

ECO

Thomas Beissinger

23-2010 Mark Spoerer,

GUNS AND BUTTER - BUT NO MARGARINE: THE IMPACT OF Jochen Streb

NAZI ECONOMIC POLICIES ON GERMAN FOOD

ECO CONSUMPTION, 1933-38 
Nr.

Autor

Titel

24-2011 Dhammika Dharmapala, Nadine Riedel

25-2011 Michael Schuele, Stefan Kirn

26-2011 Marcus Müller, Guillaume Stern, Ansger Jacob and Stefan Kirn

27-2011 Monnet Benoit, Patrick Gbakoua and Alfonso Sousa-Poza

28-2011 Nadine Riedel, Hannah SchildbergHörisch

29-2011 Nicole Waidlein

30-2011 Dominik Hartmann, Atilio Arata

31-2011 Peter Spahn

32-2011 Fabian Wahl

33-2011 Giorgio Triulzi, Ramon Scholz and Andreas Pyka

34-2011 Claus D. MüllerHengstenberg, Stefan Kirn

35-2011 Andreas Pyka

36-2011 David Bell, Steffen Otterbach and Alfonso Sousa-Poza

37-2011 Lukas Scheffknecht, Felix Geiger

38-2011 Yin Krogmann, Ulrich Schwalbe
EARNINGS SHOCKS AND TAX-MOTIVATED INCOME-SHIFTING: EVIDENCE FROM EUROPEAN MULTINATIONALS

ECO

ICT

QUALITATIVES, RÄUMLICHES SCHLIEßEN ZUR KOLLISIONSERKENNUNG UND KOLLISIONSVERMEIDUNG AUTONOMER BDI-AGENTEN

VERHALTENSMODELLE FÜR SOFTWAREAGENTEN IM ICT PUBLIC GOODS GAME

ECO

ENGEL CURVES, SPATIAL VARIATION IN PRICES AND

DEMAND FOR COMMODITIES IN CÔTE D'IVOIRE

ASYMMETRIC OBLIGATIONS

ECO

CAUSES OF PERSISTENT PRODUCTIVITY DIFFERENCES IN THE WEST GERMAN STATES IN THE PERIOD FROM 1950 TO 1990

MEASURING SOCIAL CAPITAL AND INNOVATION IN POOR AGRICULTURAL COMMUNITIES. THE CASE OF CHÁPARRA PERU

DIE WÄHRUNGSKRISENUNION

DIE EURO-VERSCHULDUNG DER NATIONALSTAATEN ALS SCHWACHSTELLE DER EWU

ECO

DIE ENTWICKLUNG DES LEBENSSTANDARDS IM DRITTEN REICH - EINE GLÜCKSÖKONOMISCHE PERSPEKTIVE

ECO

R\&D AND KNOWLEDGE DYNAMICS IN UNIVERSITY-INDUSTRY

IK RELATIONSHIPS IN BIOTECH AND PHARMACEUTICALS: AN AGENT-BASED MODEL

ANWENDUNG DES ÖFFENTLICHEN VERGABERECHTS AUF MODERNE IT SOFTWAREENTWICKLUNGSVERFAHREN

ICT

AVOIDING EVOLUTIONARY INEFFICIENCIES

IK IN INNOVATION NETWORKS

WORK HOURS CONSTRAINTS AND HEALTH

$\mathrm{HCM}$

A BEHAVIORAL MACROECONOMIC MODEL WITH

ECO ENDOGENOUS BOOM-BUST CYCLES AND LEVERAGE DYNAMICS

INTER-FIRM R\&D NETWORKS IN THE GLOBAL PHARMACEUTICAL BIOTECHNOLOGY INDUSTRY DURING 1985-1998: A CONCEPTUAL AND EMPIRICAL ANALYSIS 
Nr.

39-2011 Michael Ahlheim, Tobias Börger and Oliver Frör

40-2011 Tobias Börger

41-2011 Ralf Rukwid, Julian P. Christ
RESPONDENT INCENTIVES IN CONTINGENT VALUATION: THE ECO ROLE OF RECIPROCITY

A DIRECT TEST OF SOCIALLY DESIRABLE RESPONDING IN CONTINGENT VALUATION INTERVIEWS

ECO

QUANTITATIVE CLUSTERIDENTIFIKATION AUF EBENE

IK DER DEUTSCHEN STADT- UND LANDKREISE (1999-2008) 
Nr.

Autor

Titel

42-2012 Benjamin Schön,

A TAXONOMY OF INNOVATION NETWORKS

IK

Andreas Pyka

43-2012 Dirk Foremny, Nadine Riedel

BUSINESS TAXES AND THE ELECTORAL CYCLE

ECO

44-2012 Gisela Di Meglio, Andreas Pyka and

VARIETIES OF SERVICE ECONOMIES IN EUROPE

IK

Luis Rubalcaba

45-2012 Ralf Rukwid, Julian P. Christ

INNOVATIONSPOTENTIALE IN BADEN-WÜRTTEMBERG:

IK

PRODUKTIONSCLUSTER IM BEREICH „METALL, ELEKTRO, IKT“ UND REGIONALE VERFÜGBARKEIT AKADEMISCHER FACHKRÄFTE IN DEN MINT-FÄCHERN

46-2012 Julian P. Christ,

INNOVATIONSPOTENTIALE IN BADEN-WÜRTTEMBERG:

IK Ralf Rukwid BRANCHENSPEZIFISCHE FORSCHUNGS- UND ENTWICKLUNGSAKTIVITÄT, REGIONALES PATENTAUFKOMMEN UND BESCHÄFTIGUNGSSTRUKTUR

47-2012 Oliver Sauter

ASSESSING UNCERTAINTY IN EUROPE AND THE

ECO US - IS THERE A COMMON FACTOR?

IK

SEN MEETS SCHUMPETER. INTRODUCING STRUCTUR
DYNAMIC ELEMENTS INTO THE HUMAN CAPABILITY APPROACH

49-2012 Harold ParedesFrigolett, Andreas Pyka

DISTAL EMBEDDING AS A TECHNOLOGY INNOVATION

IK NETWORK FORMATION STRATEGY

CYCLICALITY OF REAL WAGES IN THE USA AND GERMANY: NEW INSIGHTS FROM WAVELET ANALYSIS

ECO

Martyna Marczak Víctor Gómez

DIE DURCHSETZUNG VON SCHNITTSTELLEN

IK IN DER STANDARDSETZUNG:

FALLBEISPIEL LADESYSTEM ELEKTROMOBILITÄT

52-2012 Fabian Wahl

WHY IT MATTERS WHAT PEOPLE THINK - BELIEFS, LEGAL

ECO ORIGINS AND THE DEEP ROOTS OF TRUST

IK

Micha Kaiser

STATISTISCHER ÜBERBLICK DER TÜRKISCHEN MIGRATION IN BADEN-WÜRTTEMBERG UND DEUTSCHLAND

IDENTIFIZIERUNG UND ANALYSE DEUTSCH-TÜRKISCHER INNOVATIONSNETZWERKE. ERSTE ERGEBNISSE DES TGIN-

Andreas Pyka, Seda Aydin, Lena Klauß, Fabian Stahl, Ali PROJEKTES

Santircioglu, Silvia Oberegelsbacher, Sheida Rashidi, Gaye Onan and Suna Erginkoç

55-2012 Michael Ahlheim, Tobias Börger and Oliver Frör DESERT: A CONTINGENT VALUATION STUDY IN RURAL SOUTHWEST CHINA 
Nr. Autor

56-2012 Matthias Strifler Thomas Beissinger

57-2012 Peter Spahn

58-2012 Sibylle H. Lehmann

59-2012 Sibylle H. Lehmann, Philipp Hauber and Alexander Opitz

60-2012 Martyna Marczak, Víctor Gómez

61-2012 Theresa Lohse, Nadine Riedel
FAIRNESS CONSIDERATIONS IN LABOR UNION WAGE SETTING - A THEORETICAL ANALYSIS

INTEGRATION DURCH WÄHRUNGSUNION? DER FALL DER EURO-ZONE

TAKING FIRMS TO THE STOCK MARKET:

IPOS AND THE IMPORTANCE OF LARGE BANKS IN IMPERIAL GERMANY 1896-1913

POLITICAL RIGHTS, TAXATION, AND FIRM VALUATION -

ECO EVIDENCE FROM SAXONY AROUND 1900

SPECTRAN, A SET OF MATLAB PROGRAMS FOR SPECTRAL

ECO ANALYSIS

THE IMPACT OF TRANSFER PRICING REGULATIONS ON PROFIT SHIFTING WITHIN EUROPEAN MULTINATIONALS
ECO

ECO

ECO

ECO 
Nr. Autor

63-2013 David E. Bloom,

AGEING AND PRODUCTIVITY

$\mathrm{HCM}$

Alfonso Sousa-Poza

64-2013 Martyna Marczak,

MONTHLY US BUSINESS CYCLE INDICATORS:

ECO Víctor Gómez

A NEW MULTIVARIATE APPROACH BASED ON A BAND-PASS FILTER

65-2013 Dominik Hartmann,

INNOVATION, ECONOMIC DIVERSIFICATION AND HUMAN

IK

Andreas Pyka

DEVELOPMENT

66-2013 Christof Ernst,

CORPORATE TAXATION AND THE QUALITY OF RESEARCH

ECO

Katharina Richter and AND DEVELOPMENT

Nadine Riede

67-2013 Michael Ahlheim, Oliver Frör, Jiang Tong, Luo Jing and Sonna Pelz

68-2013 Michael Ahlheim, Friedrich Schneider

CONSIDERING HOUSEHOLD SIZE IN CONTINGENT VALUATION STUDIES

69-2013 Fabio Bertoni, Tereza Tykvová

WHICH FORM OF VENTURE CAPITAL IS MOST SUPPORTIVE OF INNOVATION?

EVIDENCE FROM EUROPEAN BIOTECHNOLOGY COMPANIES

70-2013 Tobias Buchmann, Andreas Pyka

THE EVOLUTION OF INNOVATION NETWORKS:

THE CASE OF A GERMAN AUTOMOTIVE NETWORK Pyka, J. A. La Poutré and A. G. de Kok

72-2013 Beatriz Fabiola López Ulloa, Valerie Møller and Alfonso SousaPoza

73-2013 Wencke Gwozdz, Alfonso Sousa-Poza, Lucia A. Reisch, Wolfgang Ahrens, Stefaan De Henauw, Gabriele Eiben, Juan M. Fernández-Alvira, Charalampos Hadjigeorgiou, Eva Kovács, Fabio Lauria, Toomas Veidebaum, Garrath Williams, Karin Bammann

HOW DOES SUBJECTIVE WELL-BEING EVOLVE WITH AGE? 
Nr.

Autor

74-2013 Andreas Haas, Annette Hofmann

75-2013 Yin Krogmann, Nadine Riedel and Ulrich Schwalbe

76-2013 Peter Spahn

77-2013 Sheida Rashidi, Andreas Pyka

78-2013 Benjamin Schön, Andreas Pyka

79-2013 Irene Prostolupow, Andreas Pyka and Barbara Heller-Schuh

80-2013 Eva Schlenker, Kai D. Schmid

81-2013 Michael Ahlheim, Tobias Börger and Oliver Frör

82-2013 Fabian Wahl

83-2013 Peter Spahn

84-2013 Daniel Guffarth, Michael J. Barber
RISIKEN AUS CLOUD-COMPUTING-SERVICES:

$\mathrm{HCM}$ FRAGEN DES RISIKOMANAGEMENTS UND ASPEKTE DER VERSICHERBARKEIT

INTER-FIRM R\&D NETWORKS IN PHARMACEUTICAL

ECO, IK BIOTECHNOLOGY: WHAT DETERMINES FIRM'S CENTRALITY-BASED PARTNERING CAPABILITY?

MACROECONOMIC STABILISATION AND BANK LENDING:

ECO A SIMPLE WORKHORSE MODEL

MIGRATION AND INNOVATION - A SURVEY

IK

THE SUCCESS FACTORS OF TECHNOLOGY-SOURCING THROUGH MERGERS \& ACQUISITIONS - AN INTUITIVE METAANALYSIS

TURKISH-GERMAN INNOVATION NETWORKS IN THE EUROPEAN RESEARCH LANDSCAPE

IK

ECO

CAPITAL INCOME SHARES AND INCOME INEQUALITY IN THE EUROPEAN UNION

ECO

THE INFLUENCE OF ETHNICITY AND CULTURE ON THE VALUATION OF ENVIRONMENTAL IMPROVEMENTS - RESULTS FROM A CVM STUDY IN SOUTHWEST CHINA -

DOES MEDIEVAL TRADE STILL MATTER? HISTORICAL TRADE CENTERS, AGGLOMERATION AND CONTEMPORARY ECONOMIC DEVELOPMENT

SUBPRIME AND EURO CRISIS: SHOULD WE BLAME THE ECO ECONOMISTS?

THE EUROPEAN AEROSPACE R\&D COLLABORATION

IK NETWORK

KARTELLBEKÄMPFUNG UND INTERNE KARTELLSTRUKTUREN

IK EIN NETZWERKTHEORETISCHER ANSATZ 
Nr.

Autor

86-2014 Stefan Kirn, Claus D.

INTELLIGENTE (SOFTWARE-)AGENTEN: EINE NEUE

ICT Müller-Hengstenberg HERAUSFORDERUNG FÜR DIE GESELLSCHAFT UND UNSER RECHTSSYSTEM?

87-2014 Peng Nie, Alfonso

MATERNAL EMPLOYMENT AND CHILDHOOD OBESITY IN $\mathrm{HCM}$ Sousa-Poza CHINA: EVIDENCE FROM THE CHINA HEALTH AND NUTRITION SURVEY

88-2014 Steffen Otterbach, Alfonso Sousa-Poza

JOB INSECURITY, EMPLOYABILITY, AND HEALTH:

$\mathrm{HCM}$ AN ANALYSIS FOR GERMANY ACROSS GENERATIONS

89-2014 Carsten Burhop, Sibylle H. LehmannHasemeyer

THE GEOGRAPHY OF STOCK EXCHANGES IN IMPERIAL GERMANY

ECO

90-2014 Martyna Marczak, OUTLIER DETECTION IN STRUCTURAL TIME SERIES Tommaso Proietti MODELS: THE INDICATOR SATURATION APPROACH

Andreas Pyka

92-2014 Bogang Jun, Joongho Lee

THE TRADEOFF BETWEEN FERTILITY AND EDUCATION: EVIDENCE FROM THE KOREAN DEVELOPMENT PATH

NON-FINANCIAL HURDLES FOR HUMAN CAPITAL ACCUMULATION: LANDOWNERSHIP IN KOREA UNDER JAPANESE RULE

94-2014 Michael Ahlheim, Oliver Frör, Gerhard Langenberger and Sonna Pelz

95-2014 Harold ParedesFrigolett, Andreas Pyka, Javier Pereira and Luiz Flávio Autran Monteiro Gomes

CHINESE URBANITES AND THE PRESERVATION OF RARE SPECIES IN REMOTE PARTS OF THE COUNTRY - THE EXAMPLE OF EAGLEWOOD

IK

IK

RANKING THE PERFORMANCE OF NATIONAL INNOVATION SYSTEMS IN THE IBERIAN PENINSULA AND LATIN AMERICA FROM A NEO-SCHUMPETERIAN ECONOMICS PERSPECTIVE

96-2014 Daniel Guffarth, Michael J. Barber 


\section{IMPRINT}

University of Hohenheim

Dean's Office of the Faculty of Business, Economics and Social Sciences Palace Hohenheim $1 \mathrm{~B}$

70593 Stuttgart | Germany

Fon $\quad+49(0) 71145922488$

Fax $\quad+49(0) 71145922785$

E-mail wiso@uni-hohenheim.de

Web www.wiso.uni-hohenheim.de 